\title{
Isolation and Chemical Composition of Oospore-Oogonium Walls of Phytophthora megasperma var. sojae
}

\author{
By E. LIPPMAN, D. C. ERWIN AND S. BARTNICKI-GARCIA \\ Department of Plant Pathology, University of California, \\ Riverside, California 92502, U.S.A.
}

(Received 5 June 1973)

\begin{abstract}
SUMMARY
The entire sexual apparatus (Oospore-oogonium-antheridium, or OOA) of Phytophthora megasperma var. sojae was isolated in large quantities free of mycelium. The cells were fractured in a Teflon tissue homogenizer and the wall fraction was washed with a cytoplasmic dialysate to prevent agglutination and a tendency to adhere to glassware. The wall preparations were a mixture of oospore and oogonium walls (oow) and probably unrecognizable antheridial wall fragments. The walls constituted $47 \%$ of the dry weight of the oOA. Insoluble glucans comprised almost $80 \%$ of the wall; the main component was non-cellulosic $\beta$-glucan(s) linked mainly through the 3-position. Less than $10 \%$ of the oow was cellulose. In addition to glucose, there were small amounts of mannose and glucosamine in the wall polymers. Proteins comprised about $12 \%$ of the oow; the most abundant amino acids were arginine and glycine. Hydroxyproline, a component of oomycetous hyphal walls, was also present. Readily extracted lipids varied from 2.8 to $5.9 \%$, while bound lipids comprised 5.4 to $5.9 \%$ of the wall. Most of the readily extractable lipids of the OOA were found in the walls whereas bound lipids were mainly in the cytoplasmic fraction. Sterols $(0.025 \%)$ were detected in the readily extracted lipid fraction. Phosphorus amounted to $0.55 \%$ of the oow. There was substantial similarity in gross chemical composition between oow and hyphal walls of Phytophthora spp.
\end{abstract}

\section{INTRODUCTION}

This work is part of an investigation of the biochemistry of wall differentiation in Phytophthora. Previous reports from our laboratory dealt with the structure and biochemistry of walls from hyphae, sporangia and cysts of various Phytophthora spp. (Bartnicki-Garcia, I966; Bartnicki-Garcia \& Lippman, 1967; Zevenhuizen \& Bartnicki-Garcia, I969; Tokunaga \& Bartnicki-Garcia, I97 I $a, b$ ). The present investigation of the composition of oosporeoogonium walls is an initial effort to define the biochemical basis of oosporogenesis in Phytophthora. These studies may also permit an assessment of the suspected roles of these walls in oospore dormancy and germination. Blackwell (I943b) attributed oospore dormancy to the special properties of oogonium and oospore walls. This is a commonly held view, though the mechanism of oospore dormancy has yet to be elucidated (Zentmyer \& Erwin, 1970).

Phytophthora megasperma var. sojae, the causal agent of a root and stem rot of soybean, was chosen because it produced large quantities of oospores in homothallic cultures. Oospores as such could not be isolated. However, the entire sexual apparatus (Fig. I), oospore-oogonium-antheridium (OOA), was readily prepared free from mycelium (Partridge \& Erwin, 1969). The chemical determinations reported below pertain to a mixture of 


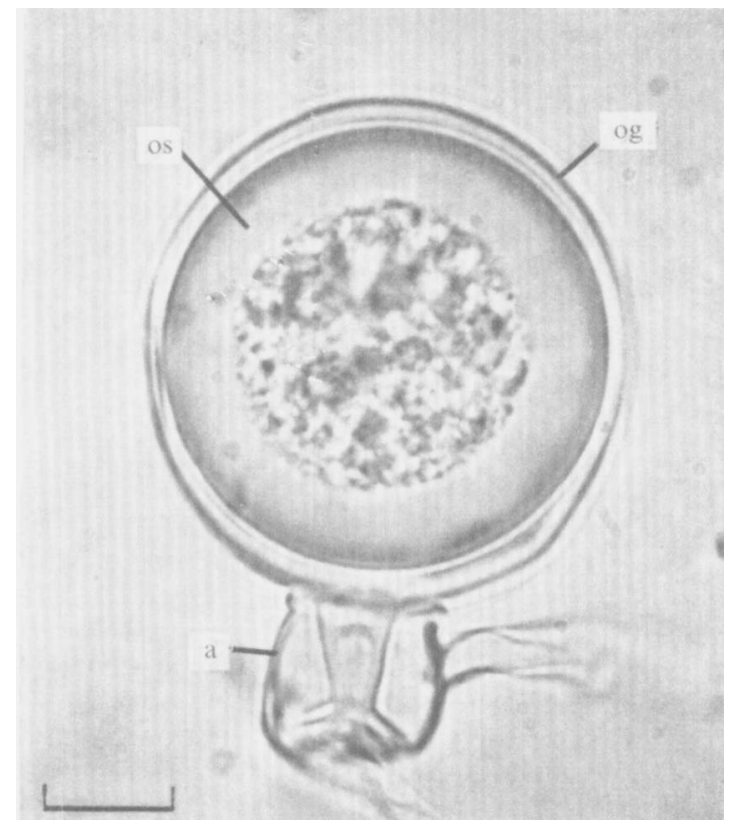

Fig. I. Cell walls in the sexual-reproductive apparatus (OOA) of Phytophthora megasperma var. sojae. $\mathrm{og}=$ Oogonium wall; $\mathrm{os}=$ oospore wall; $\mathrm{a}=$ antheridium wall. To facilitate observation of wall relationships, the specimen was mounted in $\mathrm{IN}-\mathrm{KOH}$ and stained lightly with $\mathrm{I}_{2}$. The alkali caused the oospore wall to swell and the oogonium wall to spread out smoothly over the oospore wall. $\mathrm{Bar}=\mathrm{I} 0 \mu \mathrm{m}$.

oospore and oogonium walls (oow), which we could not separate from each other, and probably unrecognized fragments of antheridial walls.

A preliminary report of this work was presented earlier (Lippman, Erwin \& BartnickiGarcia, 1971).

\section{METHODS}

Microbiological techniques. A single-oospore isolate of Phytophthora megasperma var. sojae ( $\mathrm{P} 405$, race $\mathrm{I}$ ) was maintained on V-8 juice agar slants. The fungus was grown in $90 \mathrm{~mm}$ Petri dishes containing $10 \mathrm{ml}$ of V-8 juice agar at $25^{\circ} \mathrm{C}$ in the dark for 7 days followed by exposure for 7 days to light ( 2150 lux) for $4 \mathrm{~h}$ daily. Oospores were formed abundantly under these conditions. The cultures were frozen and stored at $-20^{\circ} \mathrm{C}$ before harvesting.

Isolation of the sexual apparatus. The entire sexual reproductive apparatus consisting of the oospore, oogonium and antheridium (OOA) was removed in large numbers from associated mycelium (and agar) by repeated cycles of homogenization and centrifugation. All isolation procedures were performed at $4{ }^{\circ} \mathrm{C}$. The contents of Io frozen culture plates were homogenized in $100 \mathrm{ml}$ water with a Waring blender for $2 \mathrm{~min}$, diluted to $500 \mathrm{ml}$ with water, and centrifuged for I min at $\mathrm{I} 500 \mathrm{~g}$. The resulting sediment contained an upper layer of agar and mycelium and a lower layer of OoA. These layers were separated with a Pasteur pipette. The agar-mycelium layer was rehomogenized and sedimented until an ooA pellet was no longer obtained. The combined ooA pellets were homogenized in a Sorvall Omni-mixer $(50 \mathrm{ml}$ chamber) at $10000 \mathrm{rev} . / \mathrm{min}$ for I min. The homogenate was diluted with water and centrifuged at $1500 \mathrm{~g}$. Contaminating agar and mycelial fragments sedimented above the OOA 

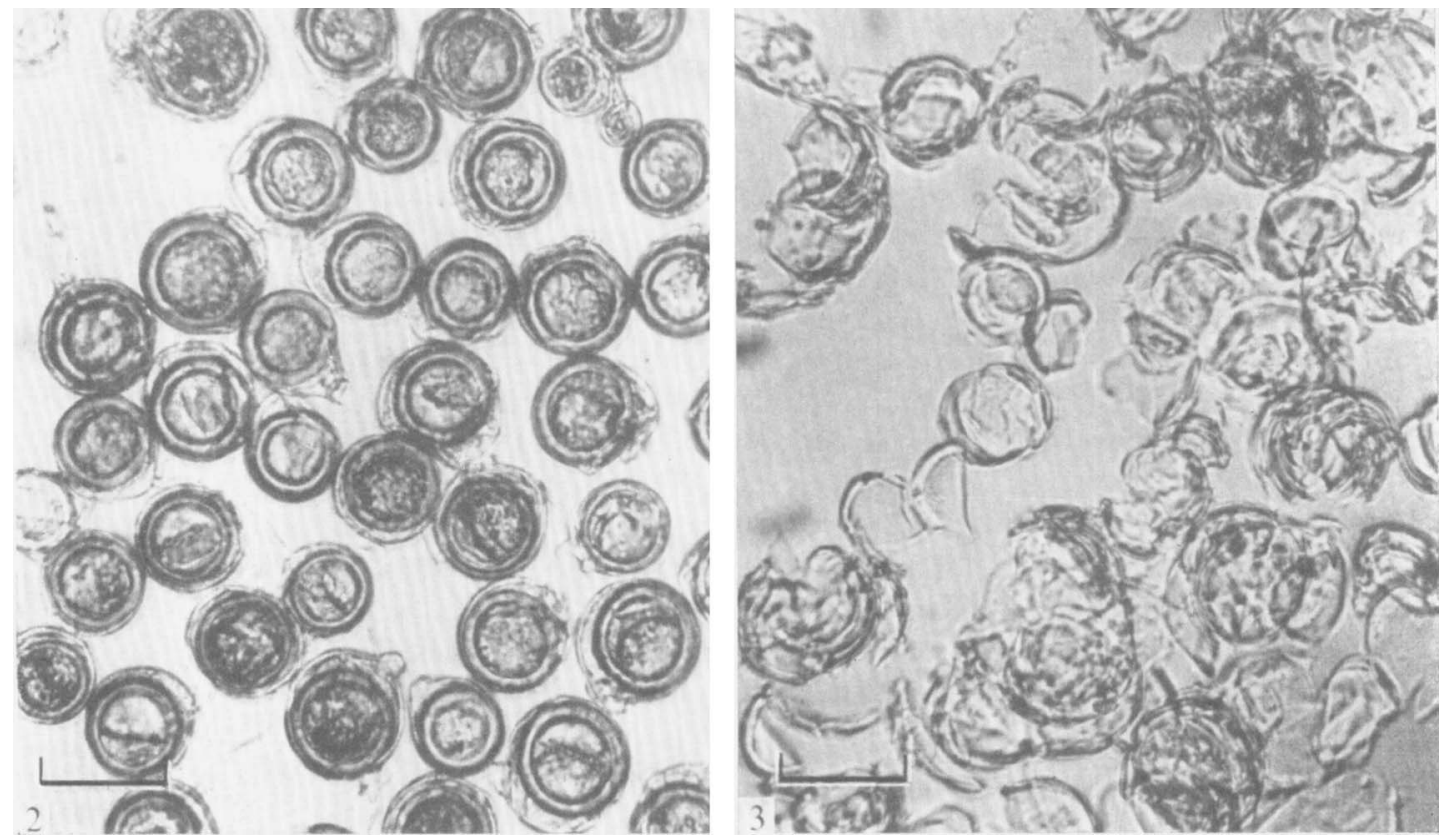

Fig. 2. Purified sample of oospore-oogonium-antheridium structures, OoA, of Phytophthora megasperma var. sojae. Stained with $\mathrm{I}_{2}$. Bar $=40 \mu \mathrm{m}$.

Fig. 3. Purified sample of oospore-oogonium walls, oow, of Phytophthora megasperma var. sojae.

Stained with $\mathrm{I}_{2}$. Bar $=40 \mu \mathrm{m}$.

pellet and were removed with a Pasteur pipette. The procedure was repeated until the OOA pellet was free of mycelium and agar (Fig. 2). The samples were then lyophilized.

A second simpler procedure for OOA isolation was developed and the samples thus obtained were used for some of the analytical work (sterol analysis). The contents of four culture plates were homogenized in $100 \mathrm{ml}$ cold water for $4 \mathrm{~min}$ in a Sorvall Omni-mixer. Small portions of the homogenate were forcibly washed through a double layer of nylon net (Ioo mesh) with cold water. After the filtrate was centrifuged for $2 \mathrm{~min}$ at $1000 \mathrm{~g}$, the supernatant and the fluffy white upper sediment containing mycelium and agar were discarded. The tancoloured OOA pellets were collected. The homogenization and filtration procedure was repeated until the material retained by the filter no longer contained OOA. Combined OOA pellets were centrifuged and the upper white sediment discarded. The OOA was again homogenized, filtered, and centrifuged. To remove small amounts of agar and mycelium, the OOA pellets were sonicated in a Raytheon Sonic Oscillator (Waltham, Massachusetts, U.S.A.) for 2 min at maximum intensity (OOA resisted sonication) and centrifuged for about I min at Iooo $g$; the supernatant and white upper sediment were discarded and the oos pellet lyophilized.

Preparation of oospore and oogonium walls (oow). Lyophilized ooA samples were suspended in water and broken in $100 \mathrm{mg}$ batches with a $17 \mathrm{ml}$ capacity Teflon Potter-Elvehjem tissue grinder (Kontes Glass Co., Vineland, New Jersey, U.S.A.) driven by an overhead stirrer for about 10 min. The broken-cell suspension was centrifuged at $75 \mathrm{~g}$. To prevent agglutination, walls were resuspended and washed in a cytoplasmic dialysate instead of water or buffer. (The cloudy supernatant from the first cell breakage was dialysed against 15 vol. distilled 
water and the outside dialysate used to resuspend the walls). The pellets were homogenized twice in the tissue grinder and sedimented at $75 \mathrm{~g}$; each sedimentation was followed by several washings with cytoplasmic dialysate. To remove small particles and lipid-like globules, the suspension was subjected to mild sonication for three 5-min intervals (ColeParmer Ultrasonic Cleaner, Model 8845-4) each followed by centrifugation at $200 \mathrm{~g}$. After the final sonication, the walls were washed by centrifugation until the supernatant was no longer turbid. The walls were then washed in distilled water to remove traces of the cytoplasmic dialysate (Fig. 3). All breakage and purification procedures were performed at $4{ }^{\circ} \mathrm{C}$. The wall preparations were lyophilized and stored over $\mathrm{P}_{2} \mathrm{O}_{5}$.

Chemical analysis. Total hexosan was determined by the anthrone procedure (Dreywood, I946), with glucose as a standard.

The hexoses were characterized as alditol acetates (Sloneker, 1972) by the following procedure. The walls were soaked at $25{ }^{\circ} \mathrm{C}$ in $22 \mathrm{~N}_{-} \mathrm{H}_{2} \mathrm{SO}_{4}$ for $3 \mathrm{~h}$. The acid was then diluted to $0.85 \mathrm{~N}$ ( $\mathrm{I} .00 \mathrm{mg}$ arabinose internal standard was added to one of the replicates) and hydrolysis was continued at $97^{\circ} \mathrm{C}$ for $4 \mathrm{~h}$. Acid was neutralized by the addition of $\mathrm{BaCO}_{3}$ and the precipitated $\mathrm{BaSO}_{4}$ was removed by filtration. Sugars were reduced with $\mathrm{NaBH}_{4}$ for $\mathrm{I}$ h. The sample was then acidified by addition of Dowex-50W-X2, hydrogen form (Bio-Rad Laboratories, Richmond, California, U.S.A.). The sample was filtered and evaporated to dryness. Methanol was added and evaporated 3 times to remove all traces of methyl borate. Alditol acetate derivatives were prepared by heating for $20 \mathrm{~min}$ at $97^{\circ} \mathrm{C}$ with equal volumes of acetic anhydride and dry pyridine. Solvents were removed by addition of toluene and evaporation to dryness. The sugars were dissolved in chloroform and separated by g.l.c. on a glass column $(200 \times 0.3 \mathrm{~cm})$ packed with $3 \%$ (w/w) ECNSS-M on chromosorb (I00 mesh) by means of a Perkin-Elmer 990 Chromatograph.

Total nitrogen (Dumas) was assayed by Elek Microanalytic Laboratories, Torrance, California, U.S.A.

Total protein was determined by the ninhydrin-hydrindantin method (Moore \& Stein, 1954) on a $6 \mathrm{~N}-\mathrm{HCl}$ acid hydrolysate as previously described (Bartnicki-Garcia \& Nickerson, 1962).

Quantitative amino-acid analyses were done on $6 \mathrm{~N}-\mathrm{HCl}$ hydrolysates according to Spackman, Stein \& Moore (1958) with a Beckman Spinco automatic amino-acid analyser. Separate analyses were performed on the I N-KOH-soluble and the $\mathrm{KOH}$-insoluble fractions of defatted (ether-ethanol extracted) oow and the results combined. Hydroxyproline was determined independently in $6 \mathrm{~N}-\mathrm{HCl}$ hydrolysates as follows. Radioactive $\left[2-{ }^{14} \mathrm{C}\right]$ hydroxyproline (Cal Atomic, mixed isomers; specific activity i $8 \cdot 5 \mathrm{Ci} / \mathrm{mol}$ ), 50000 d.p.m. was added as a marker to the neutralized hydrolysate. The amino acids were first separated by descending paper chromatography in a phenol-water system [liquified phenol:0.2 $\mathrm{M}^{-\mathrm{K}_{2}} \mathrm{HPO}_{4}$ ( $\mathrm{l} 0: \mathrm{r}, \mathrm{v} / \mathrm{v}$ ), containing 8-hydroxyquinoline $(100 \mathrm{mg} / \mathrm{l})]$. The isotope was located by using a Vanguard Autoscanner (LaGrange, Illinois, U.S.A.) and rechromatographed on paper with butan-2-ol-formic acid-water $(7: 1: 2$, by vol.). The radioactivity was eluted from the paper with water and hydroxyproline assayed chemically by using the method of Stegemann \& Stalder (1967).

Ammonia was determined from a $6 \mathrm{~N}-\mathrm{HCl}$ hydrolysate in Conway microdiffusion units by using the Nessler reaction (Ammonia Color Reagent, Sigma Chemical Co., St Louis, Missouri, U.S.A.). 2-Amino sugar was detected in $6 \mathrm{~N}-\mathrm{HCl}$ hydrolysates during the aminoacid analysis and also by the Elson--Morgan method (Tracey, I955).

Free and bound lipids were extracted as previously described and determined gravimetrically (Bartnicki-Garcia \& Nickerson, 1962). Sterols in the lipid fractions were assayed by a modification of the Liebermann-Burchard colorimetric assay (Jack, I964). 
Table I. Chemical composition of the oospore-oogonium wall of Phytophthora megasperma var. sojae

\section{Component}

Hexosan

Protein

Total lipid

Amino sugar

Phosphorus (P)
Method

Anthrone

Ninhydrin

Gravimetric

Elson-Morgan

Semidine-HCl
Wall dry weight

$(\%)$

$77 \cdot 9$

I I 45

$9 \cdot 96$

0.43

0.55

Total phosphorus was determined by the semidine- $\mathrm{HCl}$ procedure (Dryer, Tammes \& Routh, 1957).

Chemical fractionation. The walls were extracted with $\mathrm{I} \mathrm{N}-\mathrm{KOH}$ at $25^{\circ} \mathrm{C}$ for $30 \mathrm{~min}$. The alkali-soluble supernatant was dialysed against distilled water and the non-dialysable fraction assayed for carbohydrates and proteins. The alkali-insoluble material was then extracted with Schweizer's reagent (cuprammonium hydroxide) (Jayme \& Lang, I963) for several days under an atmosphere of nitrogen at $\mathrm{I}{ }^{\circ} \mathrm{C}$ in the dark. The soluble fraction was separated by centrifugation and the solubilized cellulose was reprecipitated by acidification with glacial acetic acid.

Enzymatic hydrolysis. Purified exo- $\beta$-I,3-glucanase from a Basidiomycete, QM806, was kindly supplied by D. E. Eveleigh of Rutgers, The State University, New Brunswick, New Jersey, U.S.A. A mixture of endo- $\beta$-I,3- and endo- $\beta$-I,4-glucanases from Streptomyces, QMB8I4, was the generous gift of E. T. Reese of U.S. Army Laboratories, Natick, Massachusetts, U.S.A. Both enzymes were used in a ratio of I mg enzyme to Io $\mathrm{mg}$ wall sample. Exo- $\beta$-I,3-glucanase digestion was carried out in $0.05 \mathrm{M}$-sodium acetate buffer, $\mathrm{pH} 4.8$, and the endo- $\beta$-glucanases in $0.05 \mathrm{M}$-sodium citrate buffer, $\mathrm{pH} 5.75$. Digestion of the walls was carried out at $50{ }^{\circ} \mathrm{C}$ for $42 \mathrm{~h}$. The enzymes were inactivated at $97^{\circ} \mathrm{C}$ for $5 \mathrm{~min}$ and the soluble supernatants assayed for hexose by the anthrone procedure. Five $\mathrm{mg}$ of oow, digested with $\mathrm{I} \mathrm{mg}$ acid phosphatase from potato (Calbiochem, La Jolla, California, U.S.A.) in $\mathrm{I} \mathrm{ml} 0.05 \mathrm{M}$-sodium acetate buffer, $\mathrm{pH} 4.5$, for $10 \mathrm{~h}$ at $37^{\circ} \mathrm{C}$, were assayed to determine phosphate solubilized.

$\mathrm{X}$-ray diffraction patterns were obtained in a Norelco $2.5 \mathrm{~kW}$ generator with a $114.6 \mathrm{~mm}$ Debye-Scherrer powder camera using $\mathrm{CuK}_{x}$ radiation.

\section{RESULTS}

Our isolate of Phytophthora megasperma var. sojae produced abundant sexual reproductive structures, OOA, on V-8 agar (Fig. I). The oogonium diameters ranged from 30 to $40 \mu \mathrm{m}$ (Fig. 2). The yield of ooA from Ioo Petri dishes was about $750 \mathrm{mg}$ dry wt.

Preparations of oow contained oospore and oogonium walls in various stages of fragmentation and probably some unrecognizable pieces of antheridium walls (Fig. 3). There were occasional unbroken OOA and hyphal fragments, but these were thought to be insignificant. Purified wall samples retained the light brown colour of the intact oospore preparations. The final yield of oow was approx. $40 \%$ of the dry wt of the oos.

Carbohydrate. Hexose polymers comprised almost $80 \%$ of the dry weight of oow of Phytophthora megasperma (Table 1). Three hexoses were identified in oow hydrolysates: glucose $(97.4 \%)$, mannose $(2 \cdot 4 \%)$, and traces of galactose. For comparative purposes similar determinations were made on hydrolysates of whole OOA. A comparison of mannose 
Table 2. Fractionation of polysaccharides of oospore-oogonium walls of Phytophthora megasperma var. sojae

\begin{tabular}{|c|c|c|}
\hline Fraction & $\begin{array}{c}\text { Total } \\
\text { carbohydrate } \\
(\%)\end{array}$ & $\begin{array}{c}\text { Wall } \\
\text { dry wt } \\
(\%)\end{array}$ \\
\hline $\begin{array}{l}\text { KOH-soluble } \\
\text { KOH-insoluble }\end{array}$ & I. 0 & 0.8 \\
\hline Schweizer-soluble (cellulose) & $8 \cdot 7$ & $6 \cdot 6$ \\
\hline Schweizer-insoluble (non-cellulosic glucan) & $90 \cdot 3$ & $68 \cdot 3$ \\
\hline
\end{tabular}

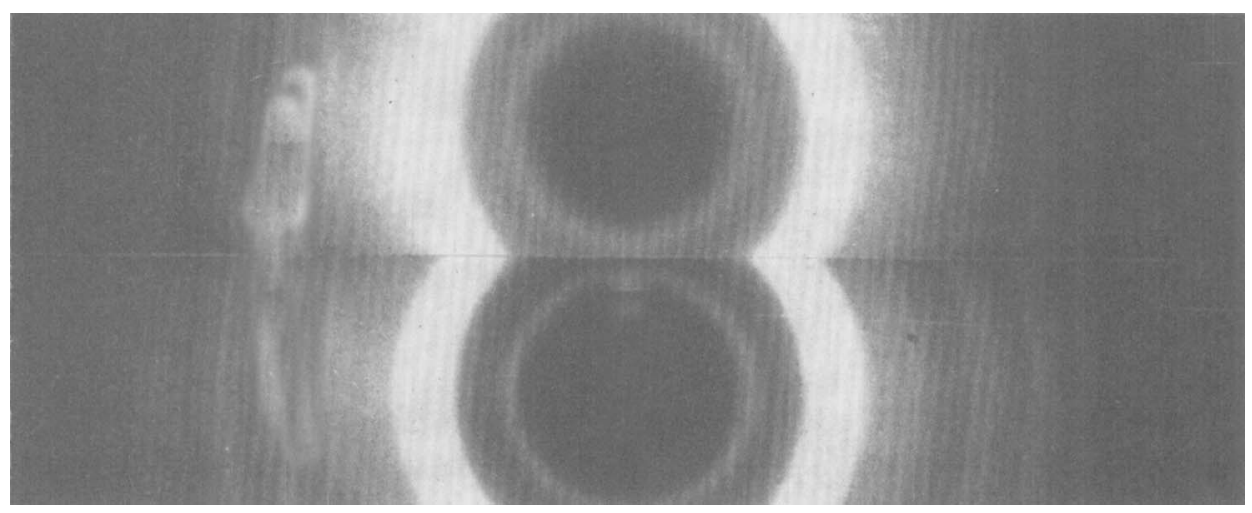

Fig. 4. X-ray diffraction patterns of regenerated cellulose from oospore-oogonium walls (top) and from Whatman paper (bottom).

content in the walls $(\mathrm{I} \cdot 65 \% \mathrm{dry} w \mathrm{wt})$ with that in the whole oospores $(\mathrm{I} \cdot \mathrm{I} \% \mathrm{dry} \mathrm{wt})$ indicated that at least $80 \%$ of the mannose in the oospore must be part of the wall if it is assumed that the walls are $47 \cdot 3 \%$ of the dry wt of the intact oospores (see below). In contrast, a similar comparison of galactose values indicated that the trace amounts of this sugar found in the wall hydrolysates were most probably of cytoplasmic origin.

An Elson-Morgan determination on a $6 \mathrm{~N}-\mathrm{HCl}$ hydrolysate revealed only a small amount of hexosamine (0.43\% wall dry wt). A glucosamine peak $(0.25 \%$ wall dry wt) was identified during the automatic amino-acid analysis. This glucosamine appeared mainly in the I N$\mathrm{KOH}$-insoluble fraction of the oow. Only a trace of the glucosamine was found in the I $\mathrm{N}-\mathrm{KOH}$-soluble fraction.

The glucans were characterized by both solubility (Table 2) and enzymic hydrolysis. Only $\mathrm{I} \%$ of the oow polysaccharides was soluble in dilute alkali. Cellulose (extracted with Schweizer's reagent and recovered by reprecipitation upon acidification) comprised only $6.6 \%$ of the oow (anthrone determination). The identity of this material was confirmed by $\mathrm{X}$-ray diffraction (Fig. 4). The main portion of these walls $(68 \%)$ was a highly insoluble noncellulosic glucan.

Microscopic comparisons of oow extracted with Schweizer's reagent and unextracted samples failed to disclose any differences indicative of a preferential location, if any, of cellulose in the oogonium or the oospore wall. However, these examinations allowed us to conclude that the principal component in either the oospore or the oogonium walls was a non-cellulosic $\beta$-glucan.

When oow samples were digested with a crude mixture of endo- $\beta$-I,4 and endo- $\beta$-I,3- 
Table 3. Amino acid composition of the oospore-oogonium wall proteins of Phytophthora megasperma var. sojae*

$\begin{array}{lcc}\text { Amino acid } & \begin{array}{c}\text { Moles } \\ (\%)\end{array} & \begin{array}{c}\text { Wall } \\ \text { dry wt } \\ (\%)\end{array} \\ \text { Alanine } & 10.14 & 0.49 \\ \text { Arginine } & 9.95 & 0.94 \\ \text { Aspartic } & 9.35 & 0.67 \\ \text { Glutamic } & 8.15 & 0.65 \\ \text { Glycine } & 20.88 & 0.85 \\ \text { Histidine } & 0.48 & 0.04 \\ \text { Hydroxyprolinet } & 3.66 & 0.26 \\ \text { Isoleucine } & \mathrm{I} .41 & 0.10 \\ \text { Leucine } & 4.22 & 0.30 \\ \text { Lysine } & 3.15 & 0.25 \\ \text { Methionine } & 0.74 & 0.06 \\ \text { Phenylalanine } & 1.79 & 0.16 \\ \text { Proline } & 5.61 & 0.35 \\ \text { Serine } & 7.37 & 0.42 \\ \text { Threonine } & 7.73 & 0.50 \\ \text { Tyrosine } & 2.54 & 0.25 \\ \text { Valine } & 2.83 & 0.18 \\ \quad \text { Total } & 100.00 & 6.48\end{array}$

* Values represent the combined total of alkali-soluble and -insoluble protein fractions from defatted samples.

$\dagger$ Determined independently.

glucanases or purified exo- $\beta$-I,3-glucanase, $50 \%$ of the wall glucans were dissolved, thus indicating a preponderance of $\beta$-I,3- linkages. Microscopic examination of oow stained with alcian blue (E. Lippman and S. Bartnicki-Garcia, unpublished) showed no ostensible change in the oogonium walls but there was substantial digestion of the oospore walls, particularly by the exo- $\beta$-I,3-glucanase.

Protein. Values of total protein as determined by the ninhydrin procedure (Table $\mathrm{I}$ ) were in agreement with a total nitrogen value of $2.01 \%$, equivalent to $12.5 \%$ protein (dry wt basis). Only about one-fifth of the wall protein was soluble in I N-KOH at room temperature.

The amino-acid composition of oow proteins is shown in Table 3 . The total amount of amino acids recovered in the automatic analysis was only $6.5 \%$ (oow dry wt). This lower yield was probably the result of destruction of amino acids as evidenced by humin formation and a relatively high $\mathrm{NH}_{3}$ content in the hydrolysate $(0.35 \%$ wall dry wt). On a molar basis, the most abundant amino acids were glycine, alanine, arginine, and aspartic and glutamic acids. Hydroxyproline, an amino acid characteristic of hyphal walls of oomycetous fungi (see Bartnicki-Garcia, 1968), was present.

Lipids. Lipid values for OOA and oow are shown in Table 4 . It follows from these data and the finding that the oow comprises $47 \%$ of the total ooA weight, that about $25 \%$ of the total lipid content of the OOA is in the walls. Furthermore, the wall contains most of the readily extractable lipids of the oospore whereas the bound lipids are largely found in the cytoplasmic fraction. Sterols were detected colorimetrically in the readily extractable lipids $(0.025 \%$ dry wt) but not in the bound lipids.

Miscellaneous. Phosphorus represented $0.55 \%$ of the wall dry weight. When digested with acid phosphatase, oow released neither phosphate nor carbohydrate into the medium.

Proportion of wall in the oospore-oogonium. The total wall volume in the oospore- 


\section{Table 4. Lipid content of intact oospore-oogonium-antheridium structures (OOA) and oospore-oogonium walls (oOw)*}

\begin{tabular}{|c|c|c|}
\hline \multirow[b]{2}{*}{ Lipid } & \multicolumn{2}{|c|}{ Dry wt $(\%)$} \\
\hline & $O O A$ & oow \\
\hline $\begin{array}{l}\text { Readily extracted } \\
\text { Bound }\end{array}$ & $\begin{array}{r}2.8 \pm 0.8 \\
16.4 \pm 5.4\end{array}$ & $\begin{array}{l}4 \cdot 2 \pm I \cdot 7 \\
5 \cdot 7 \pm 0 \cdot 2\end{array}$ \\
\hline Total & $19 \cdot 2 \pm 4 \cdot 9$ & $9 \cdot 9 \pm \mathrm{I} \cdot 7$ \\
\hline
\end{tabular}

oogonium was measured as the difference between total oogonium volume and cytoplasmic volume. To exclude as much as possible the seemingly empty space between oogonium and oospore walls, only those cells with the oogonium wall tightly adpressed against the ospore wall (for at least $50 \%$ of the cell circumference) were scored. Accordingly, the total wall volume was $64 \cdot 74 \pm 5 \cdot 24 \%$.

To estimate the dry-weight percentage of wall in intact OOA, a sample of OOA was thoroughly disrupted with a Potter-Elvehjem tissue grinder in $0 \cdot \mathrm{I} \mathrm{N}-\mathrm{NaOH}$. The wall fraction was quantitatively separated by centrifugation and its carbohydrate content measured by anthrone $(37.8 \%$ of the initial ooA dry wt). Since the unextracted oow contained $77.9 \%$ hexosan (Table I), the total amount of walls in the ooA was calculated to be $47.3 \%$. This value agrees with the yields of purified oow (37 and $42 \%$ dry wt) obtained from two different OOA batches. The latter values are, of course, minimal estimates attributable to small losses during handling.

\section{DISCUSSION}

This appears to be the first report on the chemical composition of isolated oosporeoogonium walls of Oomycetes. There have been several studies on the nature of these walls in the genus Phytophthora, but they were mainly cytochemical observations (Mangin, I 895; Dastur, I9I3; Blackwell, I943 b), the validity of which is open to question (see Aronson, 1965). Electron microscopy of sexual reproductive structures of various Oomycetes (Howard \& Moore, 1970; Gay, Greenwood \& Heath, I97I; Heath, Gay \& Greenwood, I97I ; Vujičic, 197I) provides little information on the structural organization of these walls.

Ballistic disruption (Bronwill MSK with 0.45 to $0.50 \mathrm{~mm}$ ballotini beads), the preferred method for fungal cell breakage in our laboratory, was ineffective for breaking ooA; it resulted in some walls being broken into minute fragments (difficult to recognize microscopically and difficult to separate by centrifugation) while numerous cells remained unbroken. In contrast, a Teflon tissue homogenizer, which was unsuccessful for smaller spheroidal cells such as yeast or sporangiospores of Mucor rouxii (unpublished observations), fractured essentially all OOA and yielded wall pieces that could easily be isolated. The method worked well with OOA, probably because of the relatively large size (30 to $40 \mu \mathrm{m}$ diam.).

The tendency of wall preparations to agglutinate after a few washings is an annoying problem frequently encountered in cell wall purification (Bartnicki-Garcia, 1966; Bartnicki-Garcia \& Reyes, 1968). Agglutination increases sample loss and interferes with the elimination of debris by differential centrifugation. Washing the walls with various solutions did not alleviate this problem. Since agglutination did not occur during the first two washings with distilled water, we suspected that some solute from the fungus cytoplasm was 
preventing agglutination. Accordingly, a dilute cytoplasm dialysate (diffusible fraction) was prepared and found to eliminate the agglutination problem during wall washing. The nature of the active agent(s) is not known.

Glucans comprise almost $80 \%$ of the oow. The bulk of the wall is composed of a noncellulosic $\beta$-glucan(s) linked mainly through the 3 -position. Less than $10 \%$ of the oow is cellulose. Preliminary data (P. Bardalaye and S. Bartnicki-Garcia, unpublished) indicate that this glucan is also a highly branched molecule like that found in the mycelial walls (Zevenhuizen \& Bartnicki-Garcia, I969). In addition to glucose, minor amounts of mannose and glucosamine are present. The glucose, mannose and glucosamine values are comparable to those in the mycelial walls of Phytophthora and Pythium (Bartnicki-Garcia, 1966; Mitchell \& Sabar, I966; Cooper \& Aronson, 1967; Novaes-Ledieu, Jiménez-Martínez \& Villanueva, 1967; Sietsma, Eveleigh \& Haskins, I969; Tokunaga \& Bartnicki-Garcia, I97 $b$ ). The role of the minor sugars in the walls is not known, but they could be the connecting links of glycoprotein complexes as has been found for glucosamine in the cell wall mannans of Saccharomvces cerevisiae (Sentandreu \& Northcote, 1968).

It was earlier claimed by Mangin (I895), Dastur (I9I3) and Blackwell (1943b) that cellulose was present in oospore and oogonium walls. Our results confirmed that cellulose is indeed present in the oow, but the precise location of the cellulose in either or both of these walls was not determined. Although our findings pertain to a combined analysis of oogonium and oospore walls, it was possible to conclude that the main constituent of both the oogonium and the oospore wall is a non-cellulosic $\beta-\mathrm{I}, 3$-glucan. This may represent the callose and/or the unknown compound reported earlier in oow (Mangin, I895; Dastur, I9I3; Blackwell, $1943 b$ ).

The chemical composition of the oow of Phytophthora megasperma was qualitatively similar to that of the vegetative or sporangial walls of related species of Phytophthora (Crook \& Johnston, 1962; Bartnicki-Garcia, 1966; Aronson, Cooper \& Fuller, 1967; Bartnicki-Garcia \& Lippman, I967; Novaes-Ledieu, Jiménez-Martínez \& Villanueva, 1967; Zevenhuizen \& Bartnicki-Garcia, 1969; Michell \& Scurfield, I970; Tokunaga \& Bartnicki-Garcia, I97I $b$ ) and differs only quantitatively. Significant differences in the relative proportions of components do exist, notably increased lipid and protein at the expense of a lower glucan content. The oow proteins of $P$. megasperma also differ appreciably from those of the mycelial walls of $P$. cinnamomi. In mycelial walls, threonine, glutamic acid and serine are the principal amino acids; glycine and arginine, the most abundant amino acids in oow, did not predominate in the vegetative walls. The amino-acid composition of the oow proteins was comparable to that found in most other fungal cell walls (Bartnicki-Garcia, 1973), except for the presence of hydroxyproline (commonly found among oomycetous fungi, see Bartnicki-Garcia, I968) and the unusually high arginine content.

The phosphorus content of the oow $(0.55 \%)$ was several times higher than that found in the hyphal walls of Phytophthora cinnamomi. P. parasitica (Bartnicki-Garcia, 1966) and $P$. heveae (Novaes-Ledieu, Jiménez-Martínez \& Villanueva, 1967) and the cyst and sporangial walls of $P$. palmivora (M. C. Wang, unpublished data). Unlike that in cytoplasmic phosphoglucans (Wang \& Bartnicki-Garcia, 1973), the phosphorus in the oow was not removed by phosphomonoesterases, and its nature is uncertain.

The oow contained a large amount of lipid in both free and bound forms. Lipids may be bound to the cell wall and play a structural role, e.g. they may contribute to the stiffness of the walls in Saccharomyces cerevisiae (Hurst, 1952). However, exhaustive extraction for lipids did not produce alterations in the characteristic morphology of the cells. Another possibility is that they confer hydrophobic properties to the walls which could have 
implications in dormancy and germination. These conjectures are worthy of further attention.

The oow constitute about $47 \%$ of the dry wt of the intact oOA. This is one of the highest percentages of wall material in fungal cells. Ostensibly, the thicker oospore wall is the major component of the oow.

Unequivocal roles for the oogonium and oospore wall cannot at present be ascertained; however, on germination, the internal portion of the oospore wall is markedly eroded (Blackwell, I943a; Henry \& Stelfox, 1968; Satour \& Butler, 1968; Zentmyer \& Erwin, 1970; Erwin \& McCormick, I97I) suggesting that a main role for the oospore wall is that of carbohydrate storage. The oospore wall probably supplies much of the carbon and energy needed for germination while the oogonium wall probably performs protective functions, e.g. resisting lysis by soil micro-organisms (Honour \& Tsao, 1973).

We thank G. T. James and E. A. Noltmann from the Department of Biochemistry for performing the amino-acid analyses; M. C. Wang for the phosphate determination, and J. R. Childers for one of the oospore samples.

The work was supported in part by research grant GB-32I65 from the National Science Foundation.

\section{REFERENCES}

Aronson, J. M. (1965). The cell wall. In The Fungi, An Advanced Treatise, vol. I, pp. 49-76. Edited by G. C. Ainsworth and A. S. Sussman. New York: Academic Press.

Aronson, J. M., CoOper, B. A. \& Fuller, M. S. (1967). Glucans of oomycete cell walls. Science, Washington I55, 332-335.

Bartnicki-GarCia, S. (1966). Chemistry of hyphal walls of Phytophthora. Journal of General Microbiology 42, 57-69.

Bartnicki-Garcia, S. (I968). Cell wall chemistry, morphogenesis and taxonomy of fungi. Ammal Review of Microbiology 22, 87-108.

Bartnicki-Garcia, S. (I973). Fungal cell wall composition. In Handbook of Microbiology, vol. 2. Edited by A. I. Laskin and H. A. Lechevalier. Cleveland: Chemical Rubber Press.

BARTNICKI-Garcia, S. \& Lippman, E. (1967). Enzymic digestion and glucan structure of hyphal walls of Phytophthora cinnamomi. Biochimica et biophysica acta $\mathbf{1 3 6}, 533-543$.

BartNiCKI-Garcia, S. \& Nickerson, W. J. (I962). Isolation, composition, and structure of cell walls of filamentous and yeast-like forms of Mucor rouxii. Biochimica et biophysica acta 58, 102-1 19 .

Bartnicki-Garcia, S. \& Reyes, E. (I968). Chemical composition of sporangiophore walls of Mucor rouxii. Biochimica et biophysica acta $\mathbf{1 6 5}, 32-42$.

Blackwell, E. (I943a). The life history of Phytophthora cactorum (Leb. \& Cohn) Schroet. Transactions of the British Mycological Society 26, 71-89.

Blackwell, E. (1943b). On germinating the oospores of Phytophthora cactorum. Transactions of the British Mycological Society 26, 93-103.

Cooper, B. A. \& Aronson, J. M. (1967). Cell wall structure of Pythium debaryanum. Mycologia 59, 658-670.

Crook, E. M. \& Johnston, I. R. (I962). The qualitative analysis of the cell walls of selected species of fungi. Biochemical Journal 83, 325-331.

Dastur, J. F. (1913). On Phytophthora parasitica nov. spec. A new disease of the castor oil plant. Memoirs of the Department of Agriculture in India. Botanical Series 5, 177-231.

DREYwood, R. (1946). Qualitative test for carbohydrate material. Industrial and Engineering Chemistry, Analytical Edition $\mathbf{1 8}, 499$.

Dryer, R. L., TAMmEs, A. R. \& RouTH, J. I. (1957). The determination of phosphorus and phosphatase with $N$-phenyl-p-phenylenediamine. Journal of Biological Chemistry 225, 177-1 83.

ERwin, D. C. \& McCormick, W. H. (197I). Germination of oospores produced by Phytophthora megasperma var. sojae. Mycologia 63, 972-977.

Gay, J. L., Greenwood, A. D. \& Heath, I. B. (1971). The formation and behaviour of vacuoles (vesicles) during oosphere development and zoospore germination in Saprolegnia. Journal of General Microbiology $65,233-241$. 
Heath, I. B., Gay, J. L. \& Greenwood, A. D. (I97I). Cell wall formation in the Saprolegniales: Cytoplasmic vesicles underlying developing walls. Journal of General Microbiology 65, 225-232.

HenRY, A. W. \& Stelfox, D. (1968). Comparative behaviour of the oospores and oogonia of Phytophthora citricola during germination of an artificial medium. Canadian Journal of Botany 46, I419-I42 I.

Honour, R. C. \& TSAO, P. H. (1973). Lysis of Phytophthora parasitica oospores in soil. Abstracts of papers. Second International Congress of Plant Pathology, Minneanapolis, No. 36.

HowARD, K. L. \& MOORE, R. T. (1970). Ultrastructure of oogenesis in Saprolegnia terrestris. Botanical Gazette 131, 31 I-336.

HURST, H. (1952). An electron diffraction study of the structure and orientation of the lipids in yeast and bacterial cell walls. Journal of Experimental Biology 29, 30-53.

$\mathrm{J}_{\mathrm{ACK}}$, R. C. M. (1964). Lipid metabolism in fungi. I. Lipids of the conidia of Glomerella cingulata. Contributions of the Boyce Thompson Institute for Plant Research 22, 31 I-333.

JAYME, G. \& LANG, F. (1963). Cellulose solvents. In Methods in Carbohydrate Chemistry, vol. 3, pp. 75-83. Edited by R. L. Whistler, J. W. Green, J. N. BeMiller and M. L. Wolfrom. New York: Academic Press.

Lippman, E., Erwin, D. C. \& Bartnicki-Garcia, S. (I97I). Chemical composition of the oospore-oogonium wall complex of Phytophthora megasperma var. sojae. Phytopathology 6r, $90 \mathrm{I}$.

Mangin, L. (I 895). In Recherches sur les Peronosporées, pp. 55-ro8. Société d'histoire naturelle d'Autun, Bulletin 8.

Mitchell, R. \& SABAR, N. (I966). Hyphal cell wall structure of two species of Pythium. Canadian Journal of Microbiology I2, 47I-475.

MiCheLl, A. J. \& SCURFIELD, G. (1970). An assessment of infrared spectra as indicators of fungal cell wall composition. Australian Journal of Biological Sciences 23, 345-360.

MoORE, S. \& STEIN, W. H. (I954). A modified ninhydrin reagent for the photometric determination of amino acid and related compounds. Journal of Biological Chemistry 211, 907-91 3.

Novaes-Ledieu, M., Jiménez-Martínez, A. \& Villanueva, J. R. (I967). Chemical combosition of hyphal wall of Phycomycetes. Journal of General Microbiology 47, 237-245.

Partridge, J. E. \& ERwin, D. C. (I969). Preparation of mycelium-free suspensions of oospores of Phytophthora megasperma var. sojae. Phytopathology 59, I4.

SAtour, M. M. \& ButLer, E. E. (1968). Comparative morphological and physiological studies of the progenies from intraspecific matings of Phytophthora capsici. Phytopathology 58, 183-192.

Sentandreu, R. \& NorthCote, D. H. (1968). The structure of a glycopeptide isolated from the yeast cell wall. Biochemical Journal rog, 419-432.

Sietsma, J. H., Eveleigh, D. E. \& Haskins, R. H. (1969). Cell wall composition and protoplast formation of some comycete species. Biochemica et biophysica acta 184, 306-317.

SLONEKER, J. H. (1972). Gas-liquid chromatography of alditol acetates. In Methods in Carbohydrate Chemistry, vol. 6, pp. 20-24. Edited by R. L. Whistler and J. N. BeMiller. New York: Academic Press.

SPACKMAN, D. H., STEIN, W. H. \& Moore, S. (1958). Automatic recording apparatus for use in the chromatography of amino acids. Analytical Chemistry 30, I 190-I 206.

Stegemaix, H. \& Stalder, K. (1967). Determination of hydroxyproline. Clinica chimica acta 18, 267-273.

TokUnAGA, J. \& BARTNICKI-GARCIA, S. (I97I $a$ ). Cyst wall formation and endogenous carbohydrate utilization during synchronous encystment of Phytophthora palmivora zoospores. Archiv für Mikrobiologie 79, $283-292$.

Tokunaga, J. \& Bartnicki-Garcia, S. (197i $b$ ). Structure and differentiation of the cell wall of Phytophthora palmivora: cysts, hyphae and sporangia. Archiv fïr Mikrobiologie 79, 293-310.

Tracey, M. V. (1955). Chitin. In Modern Methods of Plant Analysis, vol. 2, pp. 269-280. Edited by K. Paech and M. V. Tracey. Berlin-Göttingen-Heidelberg: Springer Verlag.

VuJičíc, R. (197I). An ultrastructural study of sexual reproduction in Phytophthora palmivora. Transactions of the Bitish Mycological Society 57, 525-530.

WANG, M. C. \& BARTNICKI-GARCIA, S. (1973). Novel phosphoglucans from the cytoplasm of Phytophthora palmivora and their selective occurrence in certain life cycle stages. Journal of Biological Chemistry 248, 4I I 2-4II8.

Zentmyer, G. A. \& Erwin, D. C. (1970). Development and reproduction of Phytophthora. Phytopathology 60, I1 20-I1 27.

Zevenhlizes, L. P. T. M. \& BARTNICKI-GARCiA, S. (I969). Chemical structure of the insoluble hyphal wall glucan of Phytophthora cinnamomi. Biochemistry 8, 1496-1502. 